Article

\title{
Study of K-Feldspar and Lime Hydrothermal Reaction: Phase and Mechanism with Reaction Temperature and Increasing $\mathrm{Ca} / \mathrm{Si}$ Ratio
}

\author{
Shanke Liu ${ }^{1,2, * \mathbb{C}}$, Cheng Han ${ }^{1,2}$ and Jianming Liu ${ }^{1,2}$ \\ 1 Key Laboratory of Mineral Resources, Institute of Geology and Geophysics, Chinese Academy of Sciences, \\ Beijing 100029, China; daxu2224@hotmail.com (C.H.); jmliu@mail.iggcas.ac.cn (J.L.) \\ 2 Institutions of Earth Science, Chinese Academy of Sciences, Beijing 100029, China \\ * Correspondence: liushanke@mail.iggcas.ac.cn; Tel.: +86-10-8299-8571
}

Received: 15 December 2018; Accepted: 9 January 2019; Published: 14 January 2019

check for updates

\begin{abstract}
To elucidate the physicochemical properties of the artificial silicate composite material, $\mathrm{K}$-feldspar and lime were reacted in mild hydrothermal conditions (different reaction temperatures and various K-feldspar/lime ratios). Formed phases were investigated using various techniques, such as X-ray powder diffraction, the Rietveld method, scanning electron microscopy (SEM), and inductively coupled plasma-optical emission spectrometry. The analysis revealed that tobermorite, grossular (hydrogarnet), alpha-dicalcium silicate hydrate $\left(\alpha-\mathrm{C}_{2} \mathrm{SH}\right)$, amorphous calcium silicate hydrate, potassium carbonate, bütschliite, calcite, and calcium hydroxide formed with various conditions. Both the temperature and the $\mathrm{Ca} / \mathrm{Si}$ molar ratio in the starting material greatly affected the formation of phases, especially the generation of tobermorite and $\alpha-\mathrm{C}_{2} \mathrm{SH}$. The substitution of $\mathrm{H}_{4} \mathrm{O}_{4}$ $\leftrightarrow \mathrm{SiO}_{4}$ proceeded with the increase of the $\mathrm{Ca} / \mathrm{Si}$ molar ratio rather than the reaction temperature and the reaction time. More hydrogen was incorporated in hydrogarnet through the substitution of $\mathrm{H}_{4} \mathrm{O}_{4} \leftrightarrow \mathrm{SiO}_{4}$ with the increase of the $\mathrm{Ca} / \mathrm{Si}$ molar ratio in the starting material. Due to the properties of tobermorite as a cation exchanger and its potential applications in hazardous waste disposal, experimental parameters should be optimized to obtain better performance of the artificial silicate composite material from K-feldspar and lime hydrothermal reaction. The dissolution mechanism of K-feldspar was also discussed.
\end{abstract}

Keywords: K-feldspar; tobermorite; hydrogarnet; hydrothermal reaction; phase analysis

\section{Introduction}

Silicates are extremely important materials, both naturally and artificially, for the development of science and technology. Although there is no known way of accurately ascertaining the abundance of every mineral within the earth's crust, based on a rough estimate, silicates comprise most of the earth's crust, as shown in Figure 1 [1]. In addition, silicates are the main component of ceramics, Portland cement, and glass. Silicate-based materials as amendments such as zeolites, clays, and cementitious materials show increasing interest in the stabilization/solidification of heavy-metal contaminated soils or environments [2-4].

Recently, an artificial silicate composite material, namely a nanosubmicron mineral-based soil conditioner (NMSC) prepared by the hydrothermal reaction of K-feldspar and lime, was reported [5-7]. Field and in-house tests indicated that the artificial silicate composite material showed excellent performance and served multiple functions that were closely related to its physicochemical properties and mineral components [8,9]. Of them, both carbonates and $11 \AA$ Aobermorite contributed to $\mathrm{pH}$ improvement and the inhibition of cadmium $(\mathrm{Cd})$ uptake in rice. Tobermorite is one of the calcium silicate hydrate 
(CSH) compounds, and the main interest is related to its close relationship with the CSH phases formed during the hydration of Portland cement [10]. In addition, tobermorite may act as cation exchangers to absorb unhealthy elements and has potential applications in waste disposal [11-13]. Tobermorite is also a slow-release reservoir for some nutrients, such as $\left[\mathrm{K}^{+}\right]$and $\left[\mathrm{NH}_{4}{ }^{+}\right]$[14]. As a primary product of the hydrothermal reaction, the weight percentage of tobermorite can reach $35 \%-40 \%$ by controlling the reaction conditions.

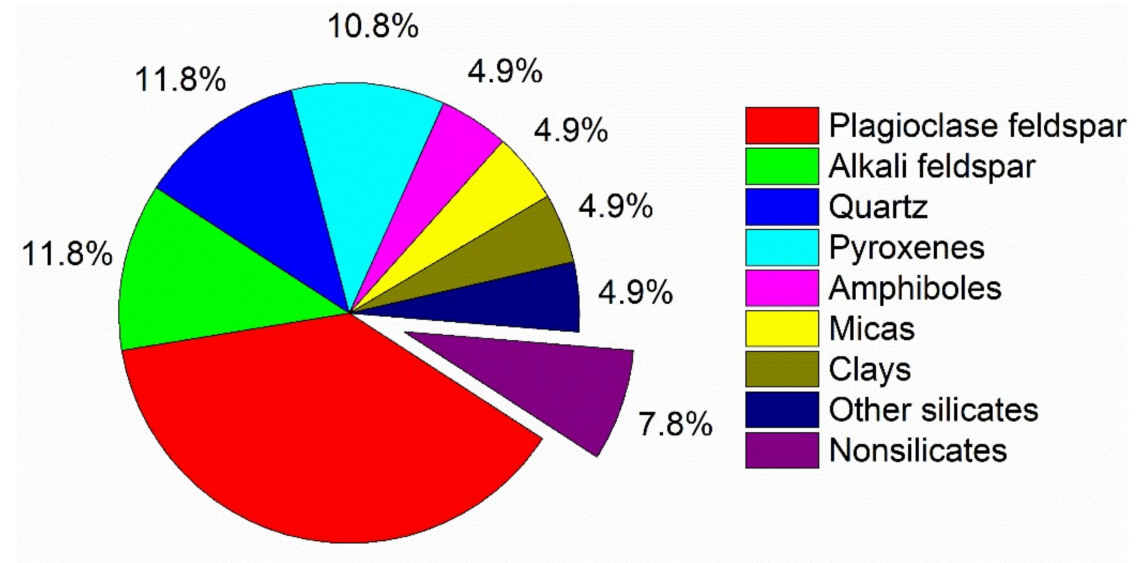

$38.2 \%$

Figure 1. Estimated volume percentages for the most common minerals in the earth's crust. The data are from the reference [1], and are normalized to $100 \%$.

In a $\mathrm{CaO}-\mathrm{Al}_{2} \mathrm{O}_{3}-\mathrm{SiO}_{2}-\mathrm{H}_{2} \mathrm{O}(\mathrm{C}-\mathrm{A}-\mathrm{S}-\mathrm{H})$ hydrothermal system, the abundance of formed minerals is closely related to the reaction conditions, such as the ratio of starting reactants [15-17]. Therefore, a study of mineral components and its abundance is a key point for the artificial silicate composite material under the different reaction conditions. We carried out a primary test on the hydrothermal reaction of K-feldspar and lime by a single-factor analysis [18]. However, at that time, the authors did not realize that the silicate composite material NMSC would show such excellent performance and serve multiple functions, as mentioned above [8,9]. Therefore, the main aim of the previous test was to improve the percentage of K-feldspar dissolution via optimizing experimental parameters. We further investigated the mechanism of the hydrothermal reaction between K-feldspar and different alkalis [including $\mathrm{Ca}(\mathrm{OH})_{2}$ ] and identified minerals formed through an elaborative interface experiment [19]. Several researchers also studied the preparation of potassium fertilizer via the hydrothermal alternation of K-feldspar ore at $200{ }^{\circ} \mathrm{C}[20,21]$. However, none of the abovementioned studies investigated the hydrothermal reaction of K-feldspar under alkaline conditions with reaction conditions, such as various reaction temperatures, various reactant ratios (the ratio of K-feldspar and lime in the starting material), and various reaction times. For a better understanding of the chemistry and mineralogy of the artificial silicate composite material, the investigation of K-feldspar and lime hydrothermal reaction must consider various conditions rather than a limited one.

Three groups of the hydrothermal experiments were carried out for investigating the K-feldspar and lime system with various conditions, i.e., the reaction temperature, the reactant ratio, and the reaction time. For each group of the hydrothermal experiment, only one factor was changed and others remained constant. The reaction temperatures of $130{ }^{\circ} \mathrm{C}$ to $250{ }^{\circ} \mathrm{C}$ were chosen for studying the effects of the reaction temperature on the hydrothermal reaction between $\mathrm{K}$-feldspar and lime. In general, the operating temperature of a common autoclave in China is approximately $190{ }^{\circ} \mathrm{C}$ in order to ensure safety during the production. Therefore, based on a view from the commercialization point, the reaction temperature of $190{ }^{\circ} \mathrm{C}$ was chosen for studying the hydrothermal reaction with the reaction time (from $0 \mathrm{~h}$ to $36 \mathrm{~h}$ ) and the reactant ratio (the ratio of $\mathrm{K}$-feldspar and lime was 3:7 to 7:3, and $10 \mathrm{~g}$ total solid mixture was fixed). The artificial silicate composite material under various hydrothermal conditions was systematically investigated by combining various techniques, such as X-ray powder diffraction 
(XRPD), the Rietveld method, scanning electron microscopy (SEM), energy dispersive X-ray spectroscopy (EDS), and inductively coupled plasma-optical emission spectrometry (ICP-OES). The material was then further analyzed from a viewpoint of chemistry and mineralogy. We published the report of the hydrothermal reaction with the reaction time in another journal [22]. Here, we only present the results of the hydrothermal reaction with the reaction temperature and the reactant ratio.

\section{Materials and Methods}

Materials and methods were briefly described in the publication of Liu et al. [18] and are stated in detail here for better understanding.

\subsection{Materials}

K-feldspar was obtained from a quarry near Geshi Town, Ningyang County, Shandong Province, China, and its chemical formula is $\left(\mathrm{K}_{0.96} \mathrm{Na}_{0.04}\right)\left(\mathrm{Al}_{1.00} \mathrm{Si}_{3.00}\right) \mathrm{O}_{8.00}$. Lime $(\mathrm{CaO}, \mathrm{AR})$ was obtained from Sinopharm Chemical Reagent Co., Ltd. (Beijing, China).

\subsection{Hydrothermal Method}

K-feldspar blocks were crushed using a jaw crusher and then pulverized by a Vibratory Disc Mill RS 200 (Retsch, Hann, Germany). Lime blocks were manually crushed and ground in an agate mortar. Both materials were sieved to a particle size of less than $74 \mu \mathrm{m}$ by a 200 -mesh screen.

\subsubsection{Reaction Temperature}

A mixture of K-feldspar powder (5.5 g), lime powder (4.5 g), and deionized water (30 mL) was homogenously blended for five minutes by a magnetic agitator at the speed of $500 \mathrm{rpm}$, and then was heated in an autoclave (100 mL volume) for $20 \mathrm{~h}$ at 130, 160, 190, 220, and $250{ }^{\circ} \mathrm{C}$. After the hydrothermal reaction ended, the reactors were naturally cooled to room temperature. For comparison, the same operation was carried out for a mixture of $5.5 \mathrm{~g}$ K-feldspar powder, $4.5 \mathrm{~g}$ lime powder, and $30 \mathrm{~mL}$ deionized water in an autoclave at room temperature $\left(25^{\circ} \mathrm{C}\right)$. Then, the production materials were removed from the autoclaves and dried at $105^{\circ} \mathrm{C}$ for $12 \mathrm{~h}$. Finally, the samples were manually crushed and ground in an agate mortar to prepare them for assessment. These corresponding production materials at $25,130,160,190,220$, and $250{ }^{\circ} \mathrm{C}$ were labeled as $\mathrm{L}-1, \mathrm{~L}-2, \mathrm{~L}-3, \mathrm{~L}-4, \mathrm{~L}-5$, and $\mathrm{L}-6$, respectively.

\subsubsection{Reactant Ratio}

A $10 \mathrm{~g}$ solid powder mixture of K-feldspar and lime was cooked along with $30 \mathrm{~mL}$ deionized water in the autoclaves at $190{ }^{\circ} \mathrm{C}$ for $13.6 \mathrm{~h}$. The mixture was obtained by homogeneously blending $\mathrm{K}$-feldspar powder and lime powder in dry conditions, and K-feldspar/lime mass ratio in the mixture was $7 / 3,6.5 / 3.5,6 / 4,5.5 / 4.5,5 / 5,4.5 / 5.5,4 / 6,3.5 / 6.5$, and 3/7, respectively. After the hydrothermal reaction was stopped, the reactors were naturally cooled to room temperature. Then, the productions were removed from those autoclaves and were dried at $105^{\circ} \mathrm{C}$ for $12 \mathrm{~h}$. Lastly, they were crushed and ground for evaluation. The hydrothermal productions for various $\mathrm{K}$-feldspar/lime mass ratios of $7 / 3$, $6.5 / 3.5,6 / 4,5.5 / 4.5,5 / 5,4.5 / 5.5,4 / 6,3.5 / 6.5$, and $3 / 7$ were labeled as $\mathrm{M}-1, \mathrm{M}-2, \mathrm{M}-3, \mathrm{M}-4, \mathrm{M}-5$, M-6, M-7, M-8, and M-9, respectively (Table S1).

\subsection{Leaching Experiment}

To analyze the chemical composition, a 1-g aliquot of each sample (fifteen samples, from L-1 to $\mathrm{L}-6$ and from $\mathrm{M}-1$ to $\mathrm{M}-9$ ) was added to $100 \mathrm{ml}$ of deionized water, and another 1-g aliquot was added to $100 \mathrm{ml}$ of $0.5 \mathrm{~mol} \cdot \mathrm{L}^{-1} \mathrm{HCl}$. Both samples were placed in a constant-temperature oscillator for one hour and filtered through filter paper. The filtered solutions and residues were conserved for further analysis. 


\subsection{Analytical Methods}

\subsubsection{SEM and EDS}

The morphology of the powdered materials was studied using a Leo 1450 VP SEM instrument (Carl Zeiss AG, Jena, Germany) under high vacuum on the uncoated specimen, operated at $20 \mathrm{kV}$ and with a beam current of $1 \mathrm{nA}$. EDS using an energy dispersive X-ray spectrometer (mounted on the scanning electron microscope, Kevex superdry EDS, Valencia, CA, USA) was performed to measure an average composition of spherical and bar particles of Sample L-6. The $\mathrm{H}$ atom was not provided by EDS because of the limited resolution.

\subsubsection{XRPD}

To distinguish the phases formed during the hydrothermal reactions, XRPD patterns of all of the powdered samples (fifteen samples, $\mathrm{L}-1$ to $\mathrm{L}-6$ and $\mathrm{M}-1$ to $\mathrm{M}-9$ ) were obtained using a Dmax2400 X-ray diffractometer (Rigaku, Tokyo, Japan) at $40 \mathrm{kV}$ and $80 \mathrm{~mA}$ in the 2 theta range from $3^{\circ}$ to $65^{\circ}$ at a step of $0.02^{\circ}$ with a counting time of $0.3 \mathrm{~s}$ per step and a total scan time of $15 \mathrm{~min} 30 \mathrm{~s}$. Quantitative phase analysis (QPA) of the XRPD results was conducted using GSAS [23] and EXPGUI [24] software with the Rietveld method [25]. The instrumental parameter file was obtained from the XRPD pattern of $\mathrm{LaB}_{6}$ standard (SRM 660b, National Institute of Standards and Technology, USA).

\subsubsection{ICP-OES}

The element concentrations in the filtrated solutions were determined using ICP-OES with IRIS advantage inductively coupled argon plasma optical emission spectrometers (Thermo Fisher Scientific Inc., Waltham, MA, USA), and its limit of detection (LOD) was $3 \sigma$ ( $\sigma$ is the standard deviation of blank determination), and the relative standard deviation (RSD) was approximately $0.5 \%-2.0 \%$.

\section{Results and Discussion}

In an early study [18], the authors performed the hydrothermal reaction using the same process as that mentioned in the experimental section. Samples of $\mathrm{L}-1$ to $\mathrm{L}-6$ and samples of $\mathrm{M}-1$ to $\mathrm{M}-9$ in this work corresponded to from LSF12-1 to LSF12-6 and from LSF11-1 to LSF11-9, respectively, in a previous work [18]. In that report, we aimed to optimize the experimental parameters by the single-factor analysis in order to improve the percentage of K-feldspar dissolution. Therefore, we have not presented the results reported in that paper yet. Here, we only show new analysis and supply additional data to better understand the physicochemical properties of K-feldspar and lime hydrothermal reactions.

\subsection{Phase}

\subsubsection{Crystal}

With the reaction temperature and the reactant ratio (the $\mathrm{Ca} / \mathrm{Si}$ molar ratio), the hydrothermal treatment of K-feldspar with lime exhibited complex product phases, including remaining K-feldspar, calcium hydroxide, calcite, grossular, tobermorite, alpha-dicalcium silicate hydrate $\left(\alpha-\mathrm{C}_{2} \mathrm{SH}\right)$, potassium carbonate, bütschliite, and amorphous calcium silicate hydrate (ACSH) (Figure 2, Table 1 and Table S2). In fact, the products were finally formed through a two-step process (Figure S1). First, calcium (alumino) silicate hydrates and potassium or calcium hydroxide were produced in the pressure-tight autoclaves during heating. Then, carbonates were formed through the reaction between their corresponding hydroxides and carbon dioxide during the drying of the sample at $105{ }^{\circ} \mathrm{C}$ in air. 

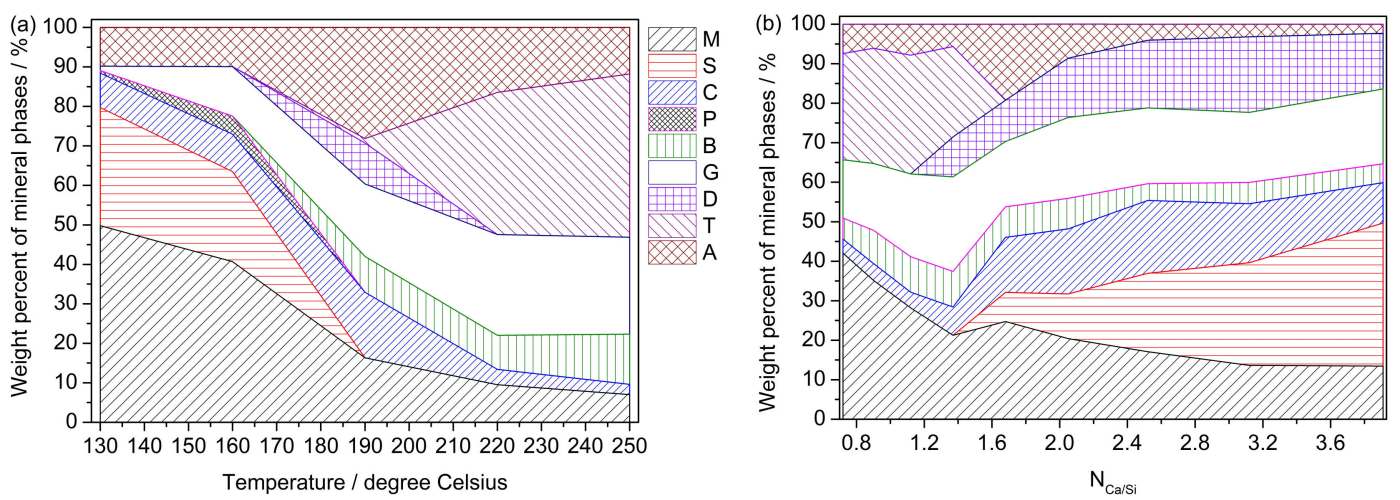

Figure 2. Results of quantitative phase analysis by the Rietveld method: (a) with reaction temperature; (b) with $\mathrm{Ca} / \mathrm{Si}$ molar ratio (see the detail of the reactant ratio in Table S1). Abbreviations: $\mathrm{M}-\mathrm{K}$-feldspar [ $\mathrm{KAlSi}_{3} \mathrm{O}_{8}$ ]; $\mathrm{S}-$ Calcium hydroxide [slaked lime (portlandite), $\mathrm{Ca}(\mathrm{OH})_{2}$ ]; $\mathrm{C}$-Calcite $\left[\mathrm{CaCO}_{3}\right]$; P-Potassium carbonate $\left[\mathrm{K}_{2} \mathrm{CO}_{3}\right]$; B-Bütschliite $\left[\mathrm{K}_{2} \mathrm{CaCO}_{3}\right]$; G-Grossular $\left[\mathrm{Ca}_{3} \mathrm{Al}_{2}\left(\mathrm{SiO}_{4}\right)_{1.53}(\mathrm{OH})_{5.88}\right] ; \mathrm{D}$-alpha-dicalcium silicate hydrate $\left[\alpha-\mathrm{C}_{2} \mathrm{SH}, \mathrm{Ca}_{2}\left(\mathrm{SiO}_{3} \mathrm{OH}\right)(\mathrm{OH})\right]$; T-Tobermorite $\left[\mathrm{Ca}_{2.25}\left(\mathrm{Si}_{3} \mathrm{O}_{7.5}(\mathrm{OH})_{1.5}\right)\left(\mathrm{H}_{2} \mathrm{O}\right)\right]$; A-Amorphous phase.

Table 1. An overview of mineral phases with various reaction conditions.

\begin{tabular}{|c|c|c|c|}
\hline Single Factor & $\mathrm{N}_{\mathrm{Ca} / \mathrm{Si}}$ & Temperature & Time $^{(b)}$ \\
\hline $\begin{array}{l}\text { Experimental } \\
\text { condition }\end{array}$ & $\begin{array}{c}\text { Temp }=190{ }^{\circ} \mathrm{C} \\
\text { Time }=13.6 \mathrm{~h} \\
0.72 \leq \mathrm{N}_{\mathrm{Ca} / \mathrm{Si}} \leq 3.91\end{array}$ & $\begin{array}{c}130{ }^{\circ} \mathrm{C} \leq \mathrm{Temp} \leq 250{ }^{\circ} \mathrm{C} \\
\text { Time }=20 \mathrm{~h} \\
\mathrm{~N}_{\mathrm{Ca} / \mathrm{Si}}=1.37\end{array}$ & $\begin{array}{c}\text { Temp }=190{ }^{\circ} \mathrm{C} \\
0 \mathrm{~h} \leq \text { Time } \leq 36 \mathrm{~h} \\
\mathrm{~N}_{\mathrm{Ca} / \mathrm{Si}}=1.37\end{array}$ \\
\hline$M^{(a)}$ & all & all & all \\
\hline S & $\mathrm{N}_{\mathrm{Ca} / \mathrm{Si}}>1.37$ & $130{ }^{\circ} \mathrm{C} \leq \mathrm{Temp}<190{ }^{\circ} \mathrm{C}$ & Time $<16 \mathrm{~h}$ \\
\hline $\mathrm{C}$ & all & all & all \\
\hline $\mathrm{P}$ & / & $130{ }^{\circ} \mathrm{C} \leq \mathrm{Temp}<190{ }^{\circ} \mathrm{C}$ & $4 \mathrm{~h}<$ Time $<16 \mathrm{~h}$ \\
\hline B & all & Temp $>160{ }^{\circ} \mathrm{C}$ & Time $>8 \mathrm{~h}$ \\
\hline G & all & all & Time $>4 \mathrm{~h}$ \\
\hline $\mathrm{D}$ & $\mathrm{N}_{\mathrm{Ca} / \mathrm{Si}}>1.12$ & $16^{\circ} \mathrm{C}<$ Temp $<220^{\circ} \mathrm{C}$ & $8 \mathrm{~h}<$ Time $<32 \mathrm{~h}$ \\
\hline $\mathrm{T}$ & $\mathrm{N}_{\mathrm{Ca} / \mathrm{Si}}<1.68$ & Temp $>160^{\circ} \mathrm{C}$ & Time $>16 \mathrm{~h}$ \\
\hline A & all & all & all \\
\hline
\end{tabular}

Note: (a) Abbreviations: M-K-feldspar [ $\mathrm{KAlSi}_{3} \mathrm{O}_{8}$ ]; S-Calcium hydroxide [slaked lime (portlandite), $\left.\mathrm{Ca}(\mathrm{OH})_{2}\right] ; \mathrm{C}$-Calcite $\left[\mathrm{CaCO}_{3}\right] ; \mathrm{P}$-Potassium carbonate $\left[\mathrm{K}_{2} \mathrm{CO}_{3}\right] ; \mathrm{B}$-Bütschliite $\left[\mathrm{K}_{2} \mathrm{CaCO}_{3}\right] ; \mathrm{G}$-Grossular $\left[\mathrm{Ca}_{3} \mathrm{Al}_{2}\left(\mathrm{SiO}_{4}\right)_{1.53}(\mathrm{OH})_{5.88}\right]$; D-alpha-dicalcium silicate hydrate $\left[\alpha-\mathrm{C}_{2} \mathrm{SH}, \mathrm{Ca}_{2}\left(\mathrm{SiO}_{3} \mathrm{OH}\right)(\mathrm{OH})\right]$; T-Tobermorite $\left[\mathrm{Ca}_{2.25}\left(\mathrm{Si}_{3} \mathrm{O}_{7.5}(\mathrm{OH})_{1.5}\right)\left(\mathrm{H}_{2} \mathrm{O}\right)\right] ; \mathrm{A}-\mathrm{Amorphous}$ phase; ${ }^{(b)}$ the data of phase with reaction time are cited from the previous work [22].

With the increase of the reaction temperature, the amount of K-feldspar decreased in terms of the quantitative phase analysis data (Figure 2 and Table S2). However, K-feldspar were still discernible when the temperature was increased to $250{ }^{\circ} \mathrm{C}$, which suggests that the K-feldspar structure is difficult to destroy under these hydrothermal conditions. All calcium hydroxide apparently reacted when the temperature reached $190{ }^{\circ} \mathrm{C}$ (Table S2). With the increasing of the Ca/Si ratio, calcium hydroxide appeared when the $\mathrm{Ca} / \mathrm{Si}$ ratio reached 1.68 , indicating that calcium hydroxide was apparently leftover. More and more calcium hydroxide was formed. The QPA results demonstrated that the amount of leftover K-feldspar decreased with the increasing Ca/Si molar ratio (Figure 2 and Table S2), and this was in accord with its decreasing ratio in the starting material. However, there still left about $13 \%$ K-feldspar when the $\mathrm{Ca} / \mathrm{Si}$ ratio reached 3.91 (the weight ratio between K-feldspar and lime is 3:7), and approximately $60 \% \mathrm{~K}$-feldspar reacted with lime in terms of an estimation. K-feldspar did not react with lime at room temperature $\left(25^{\circ} \mathrm{C}\right)$ because only calcium hydroxide and calcite were formed for L-1 while the sample was dried at $105^{\circ} \mathrm{C}$ in air (Table S2). In fact, all carbonates were formed while the sample was dried at $105^{\circ} \mathrm{C}$ in air. Calcite appeared in all the produced materials (Table 1). With the exception of potassium carbonate, the double carbonate bütschliite began to appear. 
Bütschliite can be obtained in the systems of $\mathrm{CaCO}_{3}-\mathrm{K}_{2} \mathrm{CO}_{3}-\mathrm{H}_{2} \mathrm{O}$ and $\mathrm{CaCO}_{3} / \mathrm{Ca}(\mathrm{OH})_{2}-\mathrm{KOH}-\mathrm{H}_{2} \mathrm{O}$ at room temperature [26,27]. This was proven by the fact that bütschliite, calcium hydroxide, and calcite were identified as the phases contained in the solid residue. The solid residue was obtained by vaporing a mixed solution filtrated from a mixture of a 1-g aliquot of each sample (nine samples, M-1 to M-9) and $100 \mathrm{ml}$ of deionized water (Figure S2). Therefore, potassium hydroxide, which was not detected by XRPD, reacted with calcium hydroxide and carbon dioxide to form bütschliite during the drying of the sample at $105^{\circ} \mathrm{C}$ in air.

Three crystal calcium aluminosilicate hydrates, i.e., grossular (hydrogarnet), $\alpha-\mathrm{C}_{2} \mathrm{SH}$, and tobermorite, were formed under the set hydrothermal conditions (Figure 2, Table 1 and Table S2). Higher contents of grossular and tobermorite generated at higher temperatures. Grossular stably existed after its appearance. However, the generation of $\alpha-\mathrm{C}_{2} \mathrm{SH}$ and tobermorite was greatly affected by the reaction condition. For example, with the increase in temperature, $\alpha-\mathrm{C}_{2} \mathrm{SH}$ only appeared at $190{ }^{\circ} \mathrm{C}$, and tobermorite existed from $190^{\circ} \mathrm{C}$ to $250^{\circ} \mathrm{C}$. With the increase of the $\mathrm{Ca} / \mathrm{Si}$ ratio, $\alpha-\mathrm{C}_{2} \mathrm{SH}$ stably existed after its appearance when the $\mathrm{Ca} / \mathrm{Si}$ ratio reached 1.37. However, tobermorite disappeared when the $\mathrm{Ca} / \mathrm{Si}$ ratio reached 1.68 .

The K-feldspar-lime hydrothermal system is composed of $\mathrm{K}_{2} \mathrm{O}-\mathrm{CaO}-\mathrm{Al}_{2} \mathrm{O}_{3}-\mathrm{SiO}_{2}-\mathrm{H}_{2} \mathrm{O}$, i.e., $\mathrm{K}-\mathrm{C}-\mathrm{A}-\mathrm{S}-\mathrm{H}$, which has the same elements as those of $\mathrm{CaO}-\mathrm{Al}_{2} \mathrm{O}_{3}-\mathrm{SiO}_{2}-\mathrm{H}_{2} \mathrm{O}(\mathrm{C}-\mathrm{A}-\mathrm{S}-\mathrm{H})$ except $\mathrm{K}$. However, the minerals of tobermorite, $\alpha-\mathrm{C}_{2} \mathrm{SH}$, and hydrogarnet are common phases for both systems [15-17,28-32]. Taylor summarized the phase stability of the $\mathrm{CaO}-\mathrm{SiO}_{2}-\mathrm{H}_{2} \mathrm{O}(\mathrm{C}-\mathrm{S}-\mathrm{H})$ system: $11 \AA$ A tobermorite stably exists below $200{ }^{\circ} \mathrm{C}$, and $\alpha-\mathrm{C}_{2} \mathrm{SH}$ exists below $150{ }^{\circ} \mathrm{C}[16,17]$. Meller et al. [16] determined that the phase stability was radically altered by small quantities of additives. In their study, as the upper temperature limits of $\alpha-\mathrm{C}_{2} \mathrm{SH}\left(<250{ }^{\circ} \mathrm{C}\right)$ and $11 \AA$ tobermorite $\left(<300{ }^{\circ} \mathrm{C}\right)$ increased, hydrogarnet was the only aluminum-bearing phase that was stable below $300^{\circ} \mathrm{C}$, and the presence of alumina greatly increased the stability of $11 \AA$ tobermorite. In this study, tobermorite was stable from $190{ }^{\circ} \mathrm{C}$ to $250{ }^{\circ} \mathrm{C}$, grossular was stable from $160{ }^{\circ} \mathrm{C}$ to $250{ }^{\circ} \mathrm{C}$, and $\alpha-\mathrm{C}_{2} \mathrm{SH}$ appeared only at $190{ }^{\circ} \mathrm{C}$. These results are consistent with the results obtained in the studies by Ríos et al. and Meller et al. $[15,16]$. There was no evidence that Al-substituted tobermorite was formed; however, it is possible that the $\mathrm{Al}$ substitution for $\mathrm{Si}$ in tobermorite increased its stability [33,34]. Besides, the generation of $\alpha-\mathrm{C}_{2} \mathrm{SH}$ and tobermorite was greatly affected by the initial $\mathrm{Ca} / \mathrm{Si}$ ratio in the starting material (Table 1). Here, the analysis shows that grossular was generated prior to $\alpha-\mathrm{C}_{2} \mathrm{SH}$ and tobermorite with an increase in the reaction temperature, revealing that it is easier to generate grossular than $\alpha-\mathrm{C}_{2} \mathrm{SH}$ and tobermorite under the hydrothermal conditions. Since the Ca atoms of grossular, $\alpha-\mathrm{C}_{2} \mathrm{SH}$, and tobermorite originate from lime, both $\mathrm{Si}$ and $\mathrm{Al}$ originate from $\mathrm{K}$-feldspar. Therefore, there is no competition of parallel reactions. The phase transformation is also true for $\alpha-\mathrm{C}_{2} \mathrm{SH}$ because $\alpha-\mathrm{C}_{2} \mathrm{SH}$ appeared at $190{ }^{\circ} \mathrm{C}$ and disappeared at $220^{\circ} \mathrm{C}$, showing that $\alpha-\mathrm{C}_{2} \mathrm{SH}$ is metastable and transforms to a more stable phase at higher temperatures $[17,35]$.

As a layered silicate, tobermorite has high exchangeability and selectivity for cations [11], which can alleviate the damage of heavy metals such as $\mathrm{Cd}, \mathrm{Pb}$, and $\mathrm{Cr}$ on soil $[13,36,37]$. Tobermorite is also a slow-release reservoir for some nutrients, such as $\left[\mathrm{K}^{+}\right]$and $\left[\mathrm{NH}_{4}{ }^{+}\right]$[14]. As a primary product of the hydrothermal reaction, the weight percentage of tobermorite can reach $35 \%-40 \%$ by controlling the reaction conditions (Table S2). Tobermorite has a structure similar to that of the 2:1 clay minerals, and this structure plays a key role in the soil $\mathrm{K}$ cycle [38] with a positive correlation to the $\mathrm{pH}$ buffering capacity $[39,40]$, thereby benefitting the soil.

The general formula of $11 \AA$ tobermorite may be written as $\mathrm{Ca}_{4+x}\left(\mathrm{Al}_{\mathrm{y}} \mathrm{Si}_{6-\mathrm{y}}\right) \mathrm{O}_{15+2 x-\mathrm{y}}(\mathrm{OH})_{2-2 x+y} \cdot 5 \mathrm{H}_{2} \mathrm{O}$, with $0 \leq x \leq 1$ and $0 \leq y \leq 1$. The variable $x$ represents the amount of additional calcium hosted in the structural cavities. Consequently, $11 \AA$ tobermorite is actually a series between two endmembers, $\mathrm{Ca}_{4} \mathrm{Si}_{6} \mathrm{O}_{15}(\mathrm{OH})_{2} \cdot 5 \mathrm{H}_{2} \mathrm{O}$ and $\mathrm{Ca}_{5} \mathrm{Si}_{6} \mathrm{O}_{17} \cdot 5 \mathrm{H}_{2} \mathrm{O}$ [41]. Therefore, the $\mathrm{Ca} / \mathrm{Si}$ ratio in the structure of tobermorite is $[0.67,0.83]$. Based on a magnified view of XRPD, the CSH gel phase-rather than tobermorite-was formed when the $\mathrm{Ca} / \mathrm{Si}$ ratio deviated from an ideal one in the structure of tobermorite (the star phase in Figure S3). Wang et al. [42] found that the deviation of the $\mathrm{Ca} / \mathrm{Si}$ 
molar ratio from 0.8 to 1.4 impeded the appearance of tobermorite, and this conclusion is in accord with the trend of the tobermorite appearance with the $\mathrm{Ca} / \mathrm{Si}$ ratio. However, with the increasing of the $\mathrm{Ca} / \mathrm{Si}$ ratio, it seemed beneficial for the formation of $\alpha-\mathrm{C}_{2} \mathrm{SH}$ due to its high $\mathrm{Ca} / \mathrm{Si}$ ratio. It is well known that Al-substituted tobermorite will lead an increase of the basal spacing (002) between the silicate layers along the $c$ axis and the basal spacing increases with Al content $[33,43,44]$. Compared to tobermorite synthesized without $\mathrm{Al}$, the (002) diffraction peak of samples from $\mathrm{L}-4$ to L-6, from M-1 to $\mathrm{M}-4$, and from Tm-6 to Tm-10 shifted towards lower angles (Figure 3). The content of Al for Si substitution should have been similar because two theta angles of the (002) diffraction peaks of all these samples were almost the same. Considering that the $\mathrm{Al} / \mathrm{Si}$ ratio was constant due to their shared source from K-feldspar, the conclusion seems reasonable. The EDS data showed that tobermorite contained K and $\mathrm{Al}$ atoms. Therefore, we concluded that Al-substituted tobermorite was formed (Table S6).

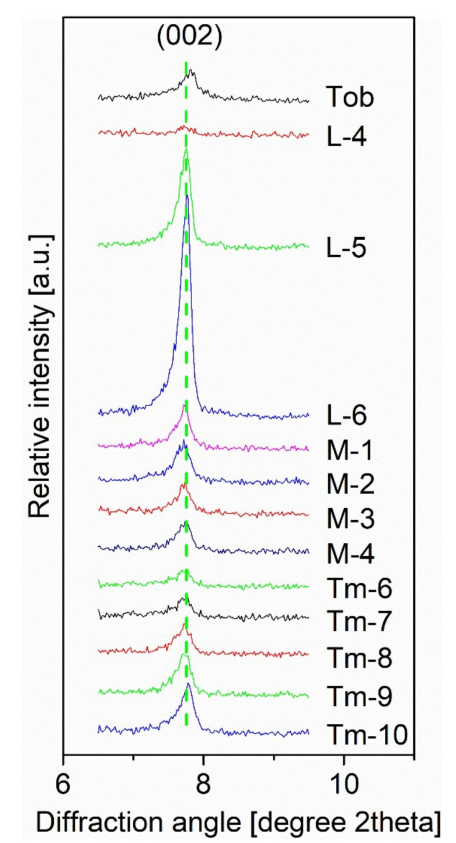

Figure 3. Enlargement of the diffraction peak of tobermorite (002). The sample (Tob) without Al was synthesized with a $0.83 \mathrm{Ca} / \mathrm{Si}$ molar ratio under the same temperature, time and water/solid ratio to those of M-1 to M-9, and Ca and Si sources were from lime and fumed silica powder, respectively. Data of Tm-6 to Tm-10 were from the previous publication [22].

The hydrogarnet is an important mineral that is often found in nature and hydrated cement. A calcic hydrogarnet that occurs frequently in the literature is hydrogrossular, $\mathrm{Ca}_{3} \mathrm{Al}_{2}\left(\mathrm{SiO}_{4}\right)_{3-\mathrm{x}}(\mathrm{OH})_{4 \mathrm{x}}$ $(0 \leq x \leq 3)$, and has intermediate compositions between grossular $(x=0)$ and katoite $(x=3)$. The structure of hydrogarnet (cubic, space group $I a \overline{3} d$, no. 230) consists of $\mathrm{AlO}_{6}$ octahedra and $\mathrm{SiO}_{4}$ tetrahedra linked with oxygen and the hydroxyl component $(\mathrm{OH})$ in a solid solution with both $(\mathrm{OH})$ and $\left(\mathrm{SiO}_{4}\right)$ units depending on the composition $x[45,46]$. A linear relationship between lattice parameter $a$ and $x$ or $a$ and Si content was observed for natural and artificial hydrogarnet [32,47,48], and a good agreement of the Si content estimates from XRD and EPMA was proven [32]. By plotting Si content $(3-x)$ against lattice parameter $a$ from the powder diffraction file (PDF) data, a linear equation was obtained for hydrogarnet (Figure 4a):

$$
3-x=48.4521-3.8529 a
$$



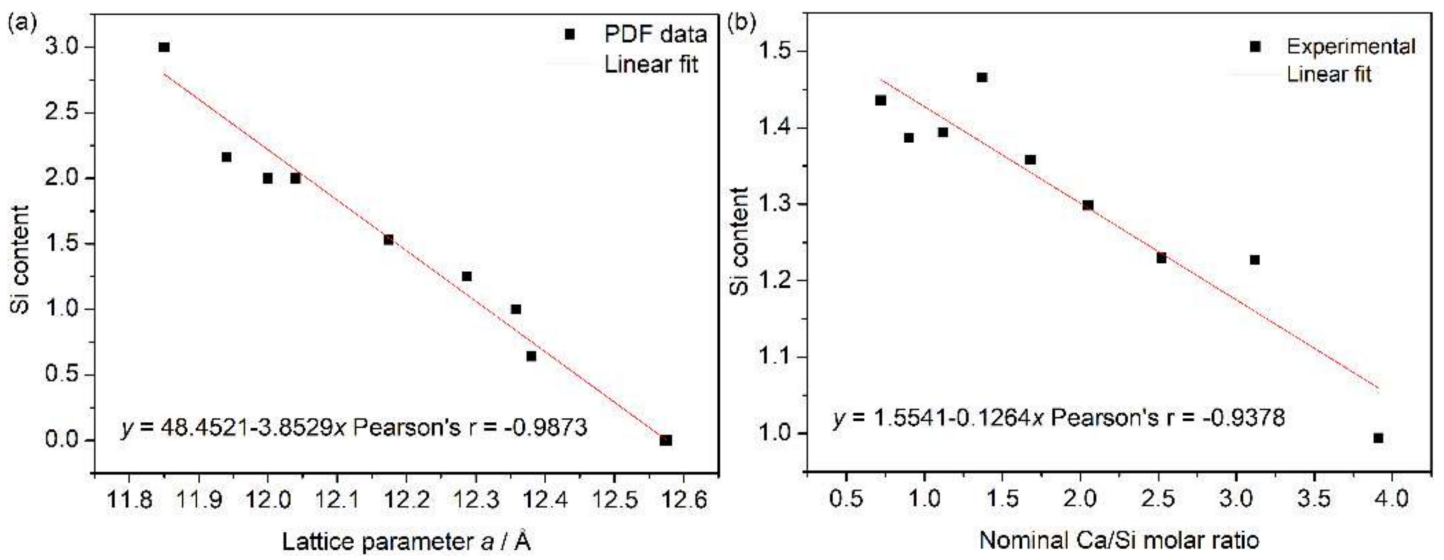

Figure 4. (a) Plot of Si content against lattice parameter $a$ of hydrogarnet from the powder diffraction file (PDF) data (see Table S4); (b) plot of Si content of hydrogarnet calculated from Equation (1) against nominal $\mathrm{Ca} / \mathrm{Si}$ molar ratio in the starting material (see Table S5).

The Si content of grossular in the samples of M-1 to M-9 was calculated from Equation (1) and was plotted against the $\mathrm{Ca} / \mathrm{Si}$ ratio in the starting material in Figure $4 \mathrm{~b}$. These values of $\mathrm{Si}$ content calculated from Equation (1) basically agreed with those obtained in terms of Figure 3 from Kyritsis et al. [32], Figure 1A from Okoronkwo and Glasser [48], and Figure 2 from Adhikari et al. [49]. It is observed from Figure $4 \mathrm{~b}$ that more hydrogen was incorporated in hydrogarnet through $\mathrm{H}_{4} \mathrm{O}_{4} \leftrightarrow \mathrm{SiO}_{4}$ with an increase of the $\mathrm{Ca} / \mathrm{Si}$ molar ratio in the starting material (nominal $\mathrm{Ca} / \mathrm{Si}$ molar ratio), which is basically consistent with the conclusion of the references [16,32]. Particularly, more hydrogen incorporation proceeded after calcium hydroxide appeared at $\mathrm{N}_{\mathrm{Ca} / \mathrm{Si}}=1.68$, which agreed with the shift of XRPD towards a lower angle for samples from M-5 to M-9 (a magnified view of the characteristic diffraction peak (420) of hydrogarent in Figure 5b). However, the ratio of $\mathrm{H}_{4} \mathrm{O}_{4} \leftrightarrow \mathrm{SiO}_{4}$ in hydrogarnet seemed to remain constant due to the same position of the diffraction peak (420) of hydrogarent for the samples of L-2 to L-6 and of Tm-3 to $\mathrm{Tm}-10$. This indicated that neither the reaction temperature nor the reaction time affected the substitution of $\mathrm{H}_{4} \mathrm{O}_{4} \leftrightarrow \mathrm{SiO}_{4}$ in hydrogarnet if there was the same $\mathrm{Ca} / \mathrm{Si}$ molar ratio in the starting material.

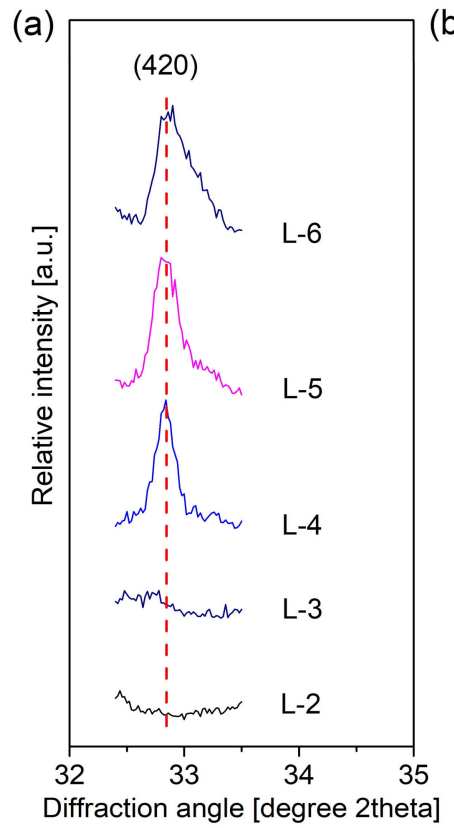

(b)

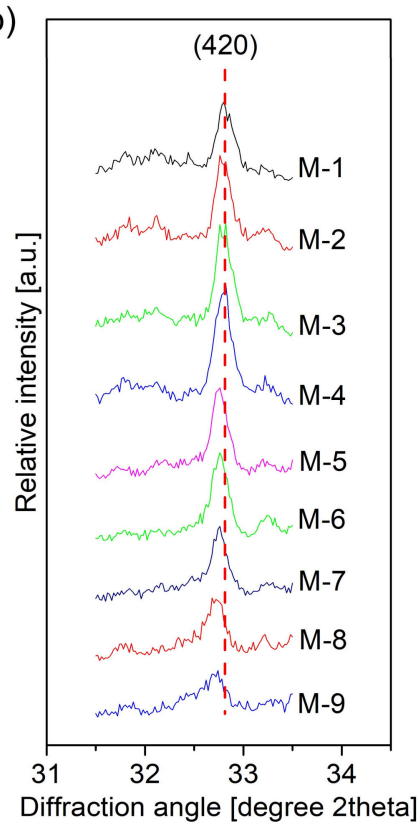

(c)

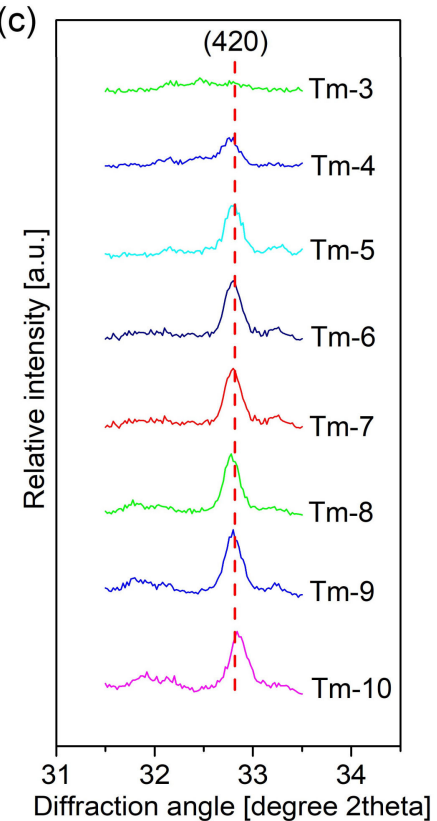

Figure 5. Diffraction peak from hydrogarnet (420) with various hydrothermal conditions: (a) reaction temperature; (b) Ca/Si molar ratio $\left(\mathrm{N}_{\mathrm{Ca} / \mathrm{Si}}\right)$; (c) reaction time (data of Tm-3 to Tm-10 were from the previous publication [22]). 
In order to obtain one single phase, some researchers used the responding oxides to prepare tobermorite and hydrogarnet. For example, tobermorite was synthesized from lime and quartz or lime and fumed silica powder under the hydrothermal condition with the designed $\mathrm{Ca} / \mathrm{Si}$ molar ratio (0.83) according to the ideal composition of tobermorite $\left(\mathrm{Ca}_{5} \mathrm{Si}_{6} \mathrm{O}_{16}(\mathrm{OH})_{2} \cdot 4 \mathrm{H}_{2} \mathrm{O}\right)[13,33$, 44,50]. Hydrogarnet was synthesized through silica gel, calcium hydroxide, and $\gamma$-alumina [51]. Therefore, the generation of the abovementioned phases was closely related to the atom ratio rather than the sources of $\mathrm{Ca}, \mathrm{Si}$, and $\mathrm{Al}$ in the starting materials. In this study, $\mathrm{Ca}$ was from lime, and $\mathrm{Al}$ and $\mathrm{Si}$ were both from K-feldspar. In terms of estimated $\mathrm{Si}$ content, the $\mathrm{Al} / \mathrm{Si}$ ratio in hydrogarnet was [1.39, 2.01], which was greater than the ratio of 1:3 in the K-feldspar structure. When one structural unit of K-feldspar was destroyed by $\mathrm{Ca}^{2+}$ and $\mathrm{OH}^{-}$attacking, $\mathrm{K}^{+}$was leached into the solution [19]. Released $\mathrm{Al}$ and $\mathrm{Si}$ combined with $\mathrm{Ca}$ to form hydrogarnet, and residual Si reacted with $\mathrm{Ca}$ to form crystal or ACSH. Al of K-feldspar mainly entered into the structure of hydrogarnet, and Si distributed in both hydrogarnet and caclium silicate hydrates.

\subsubsection{Amorphous}

With an increase in the reaction temperature and the $\mathrm{Ca} / \mathrm{Si}$ ratio, the ACSH diffraction peak was verified by a slight bump at $29^{\circ}$ for $\mathrm{M}-5$ to $\mathrm{M}-9\left(^{*}\right.$ phase in Figure S3) and L-2 to L-3 (* phase in Figure S4). This was also true for the samples of $\mathrm{Tm}-3$ to $\mathrm{Tm}-5$ with a time increase [22]. In fact, the bump corresponded to a diffraction peak of CSH gel and became a stronger diffraction peak of tobermorite when the CSH gel was transformed into tobermorite [52-55]. CSH gel is the principal hydration product and primary binding phase in $\mathrm{C}-\mathrm{A}-\mathrm{S}-\mathrm{H}$ or $\mathrm{C}-\mathrm{S}-\mathrm{H}$ systems such as Portland cement. It is generally accepted that the CSH gel phase has a tobermorite-like structure, which can be described as a layer of $\mathrm{CaO}$ polyhedra sandwiched between individual silicate chains that are organized in a "dreierketten" structure [10,56]. Some researchers confirmed that lime and Si-containing phases, such as quartz or cement, produced CSH gel with relatively low crystallinity during the hydrothermal reaction and then formed tobermorite with higher crystallinity $[57,58]$. Shaw et al. employed in situ energy-dispersive $\mathrm{X}$-ray diffraction techniques to study the hydrothermal formation of crystalline tobermorite from $190^{\circ} \mathrm{C}$ to $310^{\circ} \mathrm{C}$ [57]. First, a poorly crystalline CSH gel phase was formed. The second stage involved the ordering of the CSH gel to form ordered crystalline tobermorite. Based on the phase analysis, ACSH existed in all samples (Table S2). K-feldspar was the only residual after the product was filtrated by $0.5 \mathrm{~mol} \cdot \mathrm{L}^{-1} \mathrm{HCl}$. Therefore, these amorphous phases should have been acid soluble [22]. All formed phases were concluded to be calcium silicate hydrate or calcium aluminosilicate hydrate by EDS analysis, and the amorphous phases were mainly composed of calcium silicate hydrates or some transition state compounds that were discussed in a previous work [19]. Here, ACSH may have contained other amorphous phases-except calcium silicate hydrates—and all of these phases were judged to be amorphous by XRPD [20]. Therefore, the authors did not further determine the chemical compositions of ACSH because it was still difficult to distinguish different crystal or amorphous phases, even using Electron Probe Micro-Analyzer (EPMA) due to small particles and quantities of intertwining phases $[19,20]$.

\subsection{Morphology}

Considering the complexity of the products and the inability to identify the phases of different morphology, we do not discuss the SEM images of the samples of M-1 to M-9 and only present the SEM images of the starting materials K-feldspar and lime (Figure 6) and the samples of L-1 to L-6 (Figure 7). 


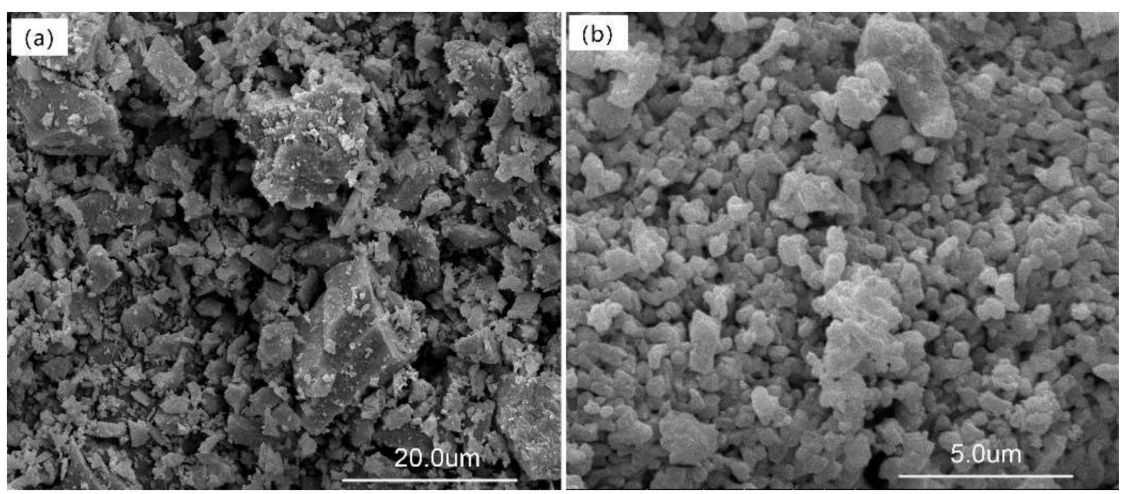

Figure 6. SEM images: (a) K-feldspar and (b) lime.
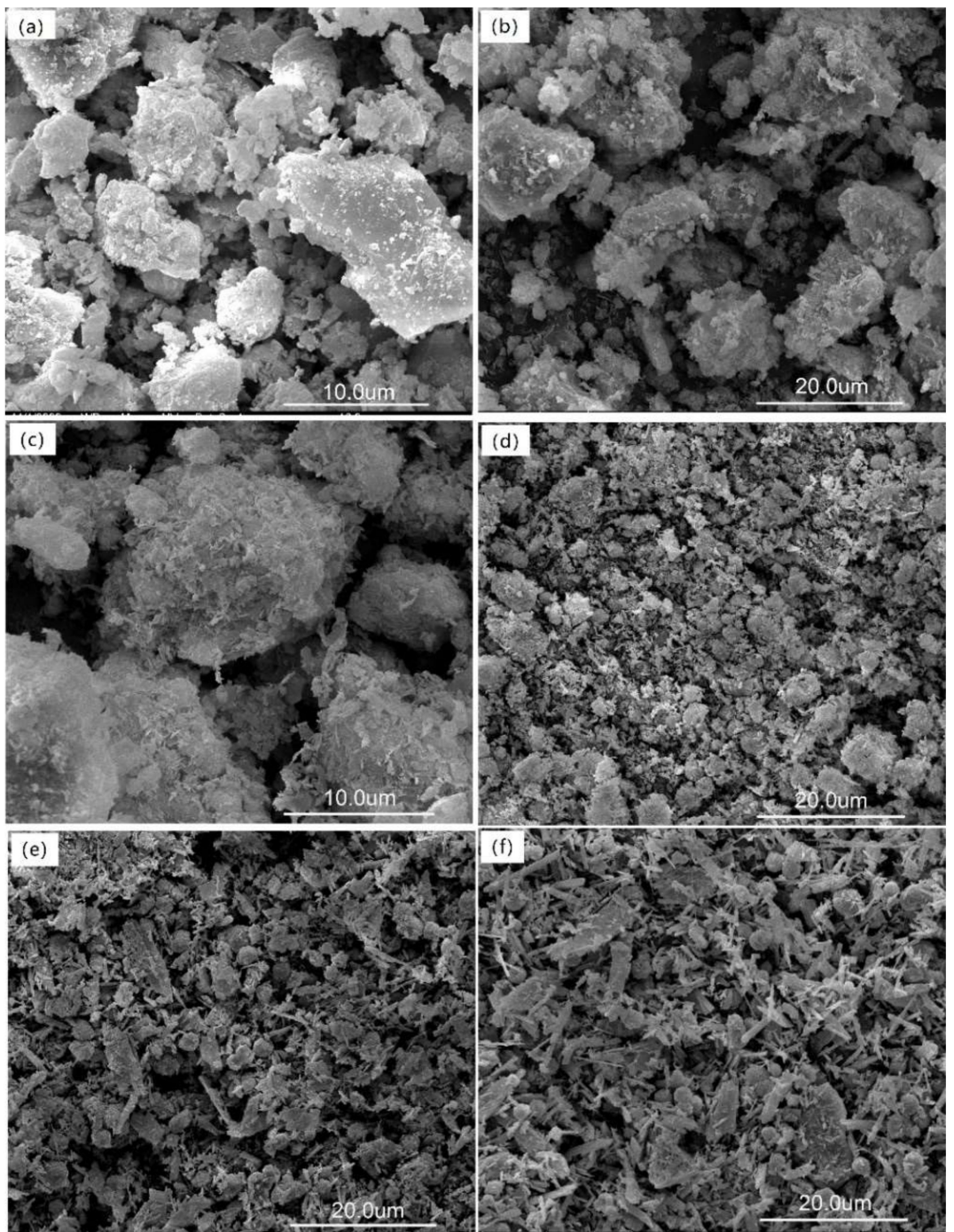

Figure 7. SEM images: (a) L-1; (b) L-2; (c) L-3; (d) L-4; (e) L-5 and (f) L-6.

Figure 6 shows that the unreacted K-feldspar powder consisted of a few to tens of micron-sized particles and that lime was composed of a few micron-sized particles, which were obviously prepared from a calcining material. When K-feldspar and lime were kept under a closed hydrothermal reactor for $13.6 \mathrm{~h}$ at room temperature, no reaction occurred. However, lime reacted with water to form calcium hydroxide and further carbonized to form calcite during the drying of the sample at $105{ }^{\circ} \mathrm{C}$ in air. Figure 7a clearly shows that several floccules adhered to the K-feldspar surface, and these floccules 
were identified as calcium hydroxide and calcite based on the XRPD results (Table S2). The morphology of the hydrothermal product L-2 was different from that of L-1. Large quantities of floccules were deposited on the surface of the K-feldspar particle, and several spherical particles appeared (Figure 7b). When the temperature was increased to $160{ }^{\circ} \mathrm{C}$, many squamiform slices appeared on the K-feldspar particles, and these slices may have been calcium hydroxide, calcite, and potassium carbonate (Figure 7c). At $190{ }^{\circ} \mathrm{C}$, the products were diverse, and it was difficult to distinguish the phases by their different morphologies (Figure 7d). At higher temperatures, the amount of spherical and laminar particles increased, which was in accordance with the QPA results demonstrating that more grossular and tobermorite were formed (Figure 7e,f). The chemical compositions of the laminar and spherical particles were determined using EDS (Figure 8 and Table $\mathrm{S} 6)$. The $\mathrm{Ca} / \mathrm{Al}$ and $\mathrm{Ca} /(\mathrm{Al}+\mathrm{Si}$ ) atom ratios determined by EDS were 1.63 and 0.62 for the spherical particle (Figure 8a), respectively, and approached the corresponding ratio values of grossular $\left[\mathrm{N}_{\mathrm{Ca} / \mathrm{Al}}=1.5 \mathrm{~N} \mathrm{Ca} /(\mathrm{Al}+\mathrm{Si})=0.85, \mathrm{Ca}_{3} \mathrm{Al}_{2}\left(\mathrm{SiO}_{4}\right)_{1.53}(\mathrm{OH})_{5.88}\right.$, PDF card number 01-075-1690]. The Ca/Si atom ratio determined by EDS was 0.72 for the laminar particle (Figure $8 \mathrm{~b}$ ) and approached its corresponding ratio value of tobermorite $\left[\mathrm{N}_{\mathrm{Ca} / \mathrm{Si}}=0.75\right.$, $\mathrm{Ca}_{2.25}\left(\mathrm{Si}_{3} \mathrm{O}_{7.5}(\mathrm{OH})_{1.5}\right)\left(\mathrm{H}_{2} \mathrm{O}\right)$, PDF card number 01-083-1520]. The spherical particle contained a $\mathrm{K}$ atom and the laminar one contained both $\mathrm{K}$ and $\mathrm{Al}$ atoms, and this may have been caused by the intertwining of the formed phases with each other. As a result, the ratio determined by EDS slightly deviated from the reference value. Therefore, in this study, the laminar phase was tobermorite, as identified in our previous study and by other researchers [19,59-62], and the spherical particle was grossular, as identified in our previous study and by other researchers [19,60,63].

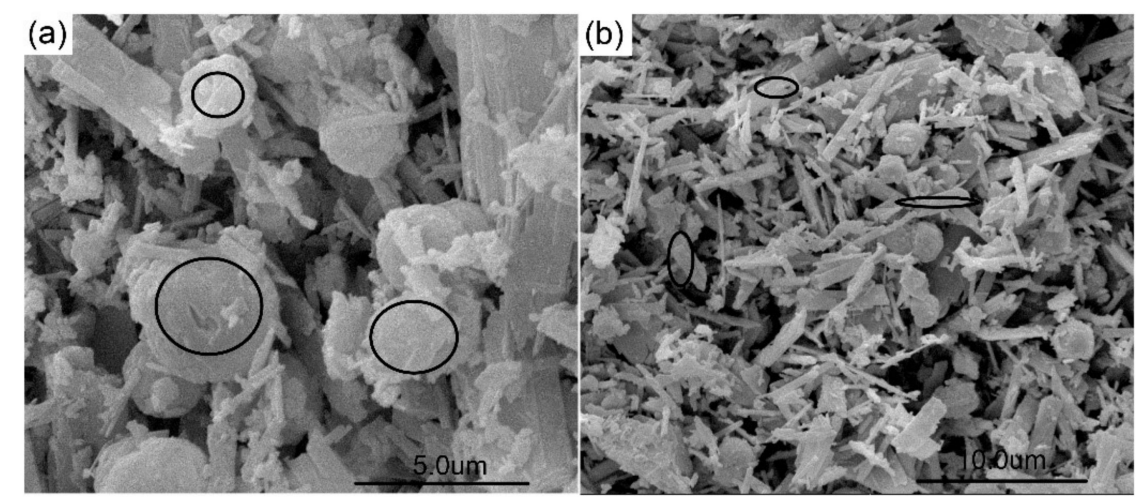

Figure 8. SEM magnified image of L-6: (a) spots of energy dispersive X-ray spectroscopy (EDS) for spherical particle; (b) spots of EDS for laminar particle. EDS were determined for the spots in the black circles.

\subsection{Dissolution Mechanism}

For investigating the dissolution mechanism of K-feldspar under hydrothermal condition, we analyzed the percentage of K-feldspar dissolution (Table S7, and the percentage of K-feldspar dissolution was calculated from their corresponding element contents in Table S3; please see the Supplementary Materials) with the reaction temperature. Because K-feldspar did not react with lime at room temperature $\left(25^{\circ} \mathrm{C}\right)$, the authors did not consider the data of K-feldspar dissolution at this temperature. Only five-point data were fitted between the natural logarithm of the dissolution percentage $(\ln D)$ and the reciprocal of the temperature $\left(1 / T, \mathrm{~K}^{-1}\right)$. When $\ln D$ versus $1 / T\left(\mathrm{~K}^{-1}\right)$ was plotted in Figure 9, a turning point was found rather than a linear relationship. As a result, the plot of $\ln D$ vs. $1 / \mathrm{T}$ could be divided into two regions: I, [130 ${ }^{\circ} \mathrm{C}, 190{ }^{\circ} \mathrm{C}$, and $\mathrm{II},\left[190{ }^{\circ} \mathrm{C}, 250{ }^{\circ} \mathrm{C}\right]$. Then, two fitted lines were applied to these two regions:

$$
\mathrm{I}: \ln D=13.4850-\frac{4346.3643}{T}(403 K \leq T \leq 463 K ; \text { Pearson's } r=-0.9914)
$$




$$
\mathrm{II}: \ln D=7.6155-\frac{1593.4882}{T}(463 K \leq T \leq 523 K ; \text { Pearson's } r=-0.9843) \text {. }
$$

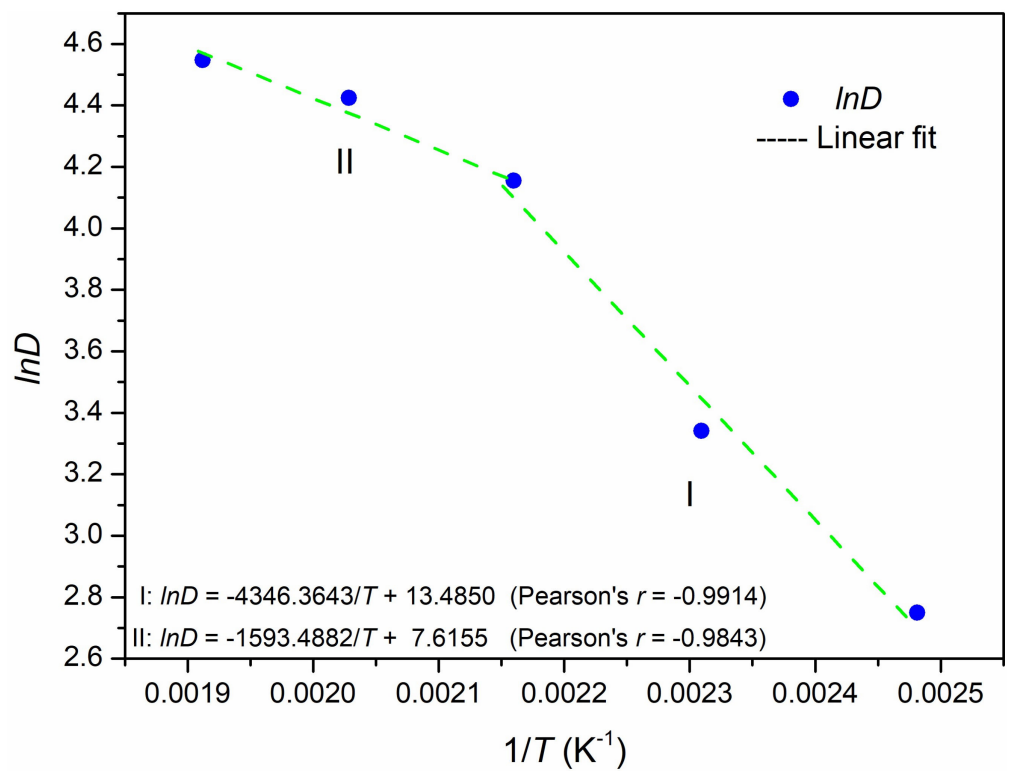

Figure 9. Natural logarithm of the percentage of dissolution $(\ln D)$ versus the reciprocal temperature $\left(1 / T, \mathrm{~K}^{-1}\right)$. $\ln D ;-$ linear fit.

In terms of the Arrhenius equation, the following represents the relationship between $\ln D$ and the dissolution apparent activation energy $E a$ :

$$
\ln D=\ln A-E a / R T .
$$

When Equation (4) was differentiated, the following equation was obtained:

$$
E a=-R \frac{d \ln D}{d\left(\frac{1}{T}\right)} .
$$

Based on Equation (5), the activation energies were calculated as $36 \mathrm{~kJ} / \mathrm{mol}$ at $130{ }^{\circ} \mathrm{C} \leq \mathrm{T} \leq 190{ }^{\circ} \mathrm{C}$ and $13 \mathrm{~kJ} / \mathrm{mol}$ at $190{ }^{\circ} \mathrm{C} \leq \mathrm{T} \leq 250^{\circ} \mathrm{C}$.

In general, $\mathrm{E} a$ is a constant over a small temperature range, which is true for regions I and II in Figure 9. Using a similar hydrothermal condition at higher temperatures $\left(260-290^{\circ} \mathrm{C}\right)$, Liu et al. [64] found a linear relationship between $\ln K$ and $1 / T$ and calculated the activation energy for the K-feldspar and slaked lime hydrothermal reaction. However, the activation energy calculated by those authors was $23 \mathrm{~kJ} / \mathrm{mol}$, which was larger than $13 \mathrm{~kJ} / \mathrm{mol}$ at $190{ }^{\circ} \mathrm{C} \leq T \leq 250{ }^{\circ} \mathrm{C}$ and less than $36 \mathrm{~kJ} / \mathrm{mol}$ at $130{ }^{\circ} \mathrm{C} \leq \mathrm{T} \leq 190^{\circ} \mathrm{C}$ in this work. It is reasonable to assume that different experimental conditions or approaches can cause a difference in the activation energy calculations [65].

From the activation energy data, we concluded that two different processes controlled the reaction, and a sketch of these processes is illustrated in Figure 10. First, the reaction was controlled by a dissolution-precipitation process (region I). At higher temperatures, the reaction was dominated by a diffusion process due to the quantities of deposited phases (region II). A similar trend was also found for the dissolution of K-feldspar with the reaction time. Through a preliminary interface study, Liu et al. [19] concluded that the reaction between K-feldspar and lime under hydrothermal conditions was a mineral-mineral replacement reaction proceeded by the dissolution-precipitation mechanism. The dissolution-precipitation mechanism was true for a reaction that occurs on the K-feldspar particle surface at medium temperatures, i.e., $160-190^{\circ} \mathrm{C}$. Under this condition, the rate of K-feldspar dissolution was close to the deposition rate of the formed phases. However, at higher 
temperatures, due to the deposition of large quantities of mineral phases on the K-feldspar surface, the diffusion of $\mathrm{K}^{+}$and $\mathrm{Ca}^{2+}$ was blocked. The mechanism in Figure 10 is consistent with the SEM results (Figure 7) because more phases were deposited on the K-feldspar surface at higher temperature.

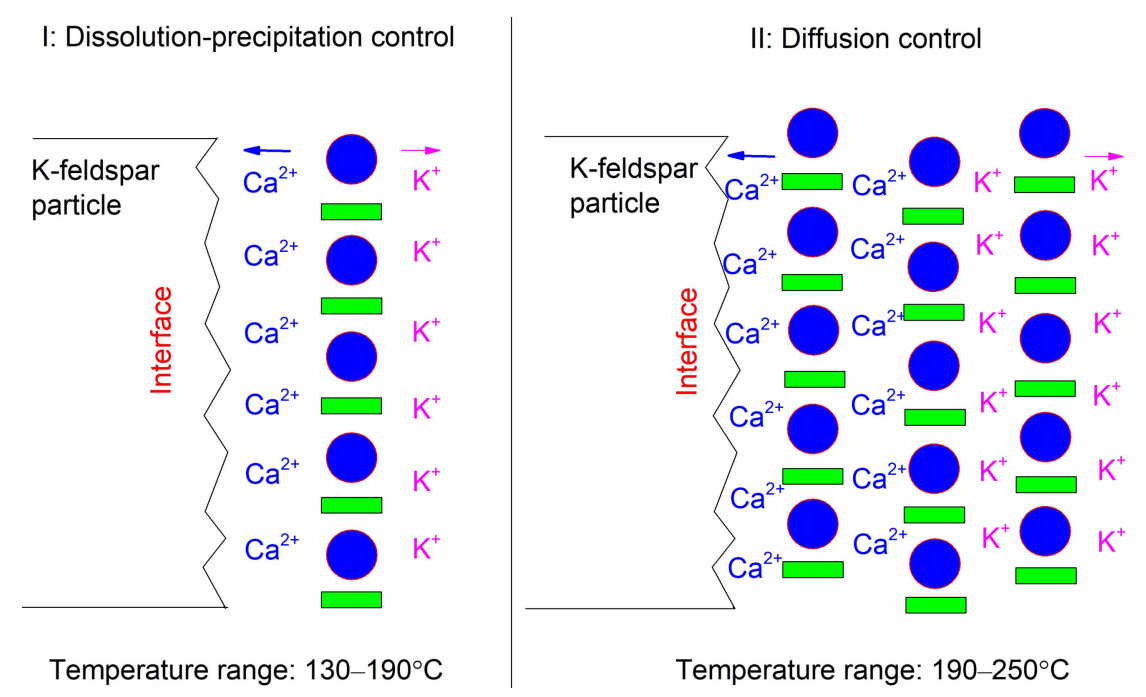

Figure 10. Hydrothermal dissolution mechanism of K-feldspar from $130{ }^{\circ} \mathrm{C}$ to $250{ }^{\circ} \mathrm{C}$.

By studying the kinetics and mechanism of the hydrothermal synthesis of barium titanate, Eckert et al. found that multiple reaction mechanisms competed in different regimes [66]. Berger et al. measured the rate of mineral dissolution of sanidine from $100{ }^{\circ} \mathrm{C}$ to $300{ }^{\circ} \mathrm{C}$ and suggested a competition between two parallel reactions at the mineral surface [67]. In this work, different reaction mechanisms dominated in various temperature regions, which is in agreement with the abovementioned conclusions.

\section{Conclusions}

Based on an environmentally friendly hydrothermal process, the artificial silicate composite material generated from natural silicate rock, i.e., K-feldspar, exhibited complex mineralogical properties. Except carbonates (namely, potassium carbonate, calcite, and bütschliite), calcium (alumno) silicates-including grossular, tobermorite, alpha-dicalcium silicate hydrate, and amorphous calcium silicate hydrate-were the main products of the K-feldspar and lime hydrothermal reaction in the $130{ }^{\circ} \mathrm{C}$ to $250{ }^{\circ} \mathrm{C}$ temperature range and in the 7:3 to 3:7 K-feldspar/lime weight ratio range (i.e., the Ca/Si molar ratio from 0.72 to 3.91 ). Both the temperature and the $\mathrm{Ca} / \mathrm{Si}$ molar ratio in the starting material greatly affected the formation of phases, especially the generation of tobermorite and $\alpha-\mathrm{C}_{2} \mathrm{SH}$. The substitution of $\mathrm{H}_{4} \mathrm{O}_{4} \leftrightarrow \mathrm{SiO}_{4}$ proceeded with the increase of the $\mathrm{Ca} / \mathrm{Si}$ molar ratio rather than the reaction temperature and the reaction time. More hydrogen was incorporated in hydrogarnet through the substitution of $\mathrm{H}_{4} \mathrm{O}_{4} \leftrightarrow \mathrm{SiO}_{4}$ with the increase of the $\mathrm{Ca} / \mathrm{Si}$ molar ratio in the starting material.

The dissolution mechanism analysis showed that a turning point between the natural logarithm of the percentage of $\mathrm{K}$-feldspar dissolution and the reciprocal of the temperature $\left(\mathrm{K}^{-1}\right)$ appeared, implying that different reaction mechanisms controlled K-feldspar dissolution. The apparent activation energies were also calculated.

Based on the results of phase analysis and from a point of environmental and economic views, the mass ratio of K-feldspar and lime should be more than 55:45 to obtain optimized properties of synthesized silicate composite material. More lime in the starting materials means higher product cost due to the higher price compared with K-feldspar. However, because of the properties of tobermorite as a cation exchanger and its potential applications in hazardous waste disposal, experimental parameters should be optimized to obtain better performance of the artificial silicate composite material from the K-feldspar and lime hydrothermal system. A detailed study is worthy of being carried out 
for investigating the relationship between the mineralogy and the function of the artificial silicate composite material.

As a potential sustainable agromineral, the artificial composite silicate material is particularly appealing, not only because of its green production process, but also because of its excellent performances and multiple functions of remediating the soil $[8,9]$. Primary studies proved that these excellent performances and functions were closely related to its physicochemical properties and mineral components [8,9]. Therefore, the study yields vital and valuable insights into comprehending the mineralogical properties of the K-feldspar and lime hydrothermal reaction and producing artificial silicate agrominerals from potassium-rich rocks.

Supplementary Materials: The following are available online at http:/ www.mdpi.com/2075-163X/9/1/46/s1, Element content and QPA; Nomenclature of grossular and hydrogarnet; Definition of the percentage of K-feldspar dissolution $(\mathrm{D}, \%)$; Table S1: Overview of the hydrothermal reaction with reactant ratio $\left(T=190{ }^{\circ} \mathrm{C}, t=13.6 \mathrm{~h}\right.$, and deionized water $=30 \mathrm{~mL}$ ); Table S2: Quantitative phase analysis by the Rietveld method (\%); Table S3: Element contents measured by ICP-OES and calculated from XRPD; Table S4: PDF data of hydrogarnet used in Figure 4a; Table S5: Estimated Si content, x, and Al/Si ratio of formed hydrogarnet from Equation (1) in this study; Table S6: EDS data of spherical and laminar particle in the sample L-6; Table S7: Percentage of K-feldspar dissolution and original data of Figure 9; Figure S1: Flow chart of mineral phases during the K-feldspar and lime hydrothermal reaction; Figure S2: XRPD of the residue of the filtrated solutions of the samples M-1 to M-9 dissolved in deionized water; Figure S3: A magnified view of XRPD pattern of M-1 to M-9 from $28.2^{\circ}$ to $35^{\circ}$; Figure S4: A magnified view of XRPD pattern of L-1 to L-6 from $28.2^{\circ}$ to $29.8^{\circ}$; Figure S5: Element contents of ICP-OES vs. XRPD: (a) the hydrothermal reaction with reaction temperature; (b) the hydrothermal reaction with reactant ratio.

Author Contributions: S.L. performed the experiments, analyzed the data and wrote the paper, C.H. and J.L. together presented the research plans and discussed the results.

Funding: This research project was supported by the Open Project Program of Key Laboratory of Mineral Resources, Institute of Geology and Geophysics, Chinese Academy of Sciences (No. KLMR2017-07), Projects in the National Science \& Technology Pillar Program during the Eleventh Five-Year Plan Period (China, No. 2006BAD10B04), and the Knowledge Innovation Project of Chinese Academy of Sciences and Spark Program of China (No. 2007EA173003).

Acknowledgments: The authors were appreciated for the precious comments and suggestions of the editor and two reviewers.

Conflicts of Interest: The authors declare no conflict of interest.

\section{References}

1. Klein, C.; Philpotts, A.R. Chapter 7 Igneous rock-forming minerals. In Earth Materials: Introduction to Mineralogy and Petrology, 2nd ed.; Klein, C., Philpotts, A.R., Eds.; Cambridge University Press: New York, NY, USA, 2017; p. 161.

2. Xu, Y.; Liang, X.; Xu, Y.; Qin, X.; Huang, Q.; Wang, L.; Sun, Y. Remediation of heavy metal-polluted agricultural soils using clay minerals: A review. Pedosphere 2017, 27, 193-204. [CrossRef]

3. Guo, B.; Liu, B.; Yang, J.; Zhang, S. The mechanisms of heavy metal immobilization by cementitious material treatments and thermal treatments: A review. J. Environ. Manag. 2017, 193, 410-422. [CrossRef] [PubMed]

4. Misaelides, P. Application of natural zeolites in environmental remediation: A short review. Microporous Mesoporous Mater. 2011, 144, 15-18. [CrossRef]

5. Liu, J.M.; Liu, S.K.; Han, C.; Sheng, X.B.; Qi, X.; Zhang, Z.L. Mineral technology for soil remediation and improvement: A new applied research direction from mineralogy, petrology and geochemistry. Bull. Mineral. Petrol. Geochem. 2014, 33, 556-560.

6. Han, C.; Liu, J.M. Method for Preparing Microporous Mineral Fertilizer from Silicates Rock Using Hydrothermal Chemical Reaction. Patent WO2009070953A1, 5 December 2007.

7. Han, C. Method for Producing Micropore Silicon-Potassium-Calcium Mineral Fertilizer. Patent CN101054313B, 26 April 2007.

8. Liu, S.K.; Qi, X.; Han, C.; Liu, J.M.; Sheng, X.B.; Li, H.; Luo, A.M.; Li, J.L. Novel nano-submicron mineral-based soil conditioner for sustainable agricultural development. J. Clean. Prod. 2017, 149, 896-903. [CrossRef]

9. Liu, S.K.; Li, H.; Han, C.; Sheng, X.B.; Liu, J.M. Cd inhibition and pH improvement via a nano-submicron mineral-based soil conditioner. Environ. Sci. Pollut. Res. 2017, 24, 4942-4949. [CrossRef] [PubMed] 
10. Richardson, I.G. The calcium silicate hydrates. Cem. Concr. Res. 2008, 38, 137-158. [CrossRef]

11. Komarneni, S.; Roy, D.M. Tobermorites: A new family of cation exchangers. Science 1983, 221, 647-648. [CrossRef] [PubMed]

12. Zou, J.J.; Guo, C.B.; Zhou, X.Q.; Sun, Y.J.; Yang, Z. Sorption capacity and mechanism of $\mathrm{Cr}^{3+}$ on tobermorite derived from fly ash acid residue and carbide slag. Colloids Surf. A 2018, 538, 825-833. [CrossRef]

13. Guo, X.L.; Shi, H.S. Microstructure and heavy metal adsorption mechanisms of hydrothermally synthesized Al-substituted tobermorite. Mater. Struct. 2017, 50, 10. [CrossRef]

14. Yao, Z.D.; Tamura, C.; Matsuda, M.; Miyake, M. Resource recovery of waste incineration fly ash: Synthesis of tobermorite as ion exchanger. J. Mater. Res. 1999, 14, 4437-4442. [CrossRef]

15. Rios, C.A.; Williams, C.D.; Fullen, M.A. Hydrothermal synthesis of hydrogarnet and tobermorite at $175^{\circ} \mathrm{C}$ from kaolinite and metakaolinite in the $\mathrm{CaO}-\mathrm{Al}_{2} \mathrm{O}_{3}-\mathrm{SiO}_{2}-\mathrm{H}_{2} \mathrm{O}$ system: A comparative study. Appl. Clay Sci. 2009, 43, 228-237. [CrossRef]

16. Meller, N.; Kyritsis, K.; Hall, C. The mineralogy of the $\mathrm{CaO}-\mathrm{Al}_{2} \mathrm{O}_{3}-\mathrm{SiO}_{2}-\mathrm{H}_{2} \mathrm{O}$ (CASH) hydroceramic system from 200 to $350^{\circ} \mathrm{C}$. Cem. Concr. Res. 2009, 39, 45-53. [CrossRef]

17. Meller, N.; Hall, C.; Kyritsis, K.; Giriat, G. Synthesis of cement based CaO- $\mathrm{Al}_{2} \mathrm{O}_{3}-\mathrm{SiO}_{2}-\mathrm{H}_{2} \mathrm{O}(\mathrm{CASH})$ hydroceramics at 200 and $250^{\circ} \mathrm{C}$ : Ex-situ and in-situ diffraction. Cem. Concr. Res. 2007, 37, 823-833. [CrossRef]

18. Liu, S.K.; Han, C.; Liu, J.M.; Li, H. Research of extracting potassium, silica and aluminum from potassium feldspar by hydrothermal chemical reaction. Acta Mineral. Sin. 2009, 29, 320-326.

19. Liu, S.K.; Han, C.; Liu, J.M.; Li, H. Hydrothermal decomposition of potassium feldspar under alkaline conditions. RSC Adv. 2015, 5, 93301-93309. [CrossRef]

20. Ciceri, D.; de Oliveira, M.; Allanore, A. Potassium fertilizer via hydrothermal alteration of K-feldspar ore. Green Chem. 2017, 19, 5187-5202. [CrossRef]

21. Skorina, T.; Allanore, A. Alkali Metal Ion Source with Moderate Rate of Ion Release and Methods of Forming. U.S. Patent US9340465B2, 6 May 2013.

22. Liu, S.; Han, C.; Liu, J. Study of K-feldspar and lime hydrothermal reaction at $190{ }^{\circ} \mathrm{C}$ : Phase, kinetics and mechanism with reaction time. ChemistrySelect 2018, 3, 13010-13016. [CrossRef]

23. Larson, A.C.; Von Dreele, R.B. General Structure Analysis System (GSAS); Los Alamos National Laboratory Report LAUR; Los Alamos National Laboratory: New Mexico, NM, USA, 2004; pp. 86-748.

24. Toby, B.H. EXPGUI, a graphical user interface for GSAS. J. Appl. Crystallogr. 2001, 34, 210-213. [CrossRef]

25. Rietveld, H.M. A profile refinement method for nuclear and magnetic structures. J. Appl. Crystallogr. 1969, $2,65-71$. [CrossRef]

26. Reardon, E.J.; Fagan, R. The calcite/portlandite phase boundary: Enhanced calcite solubility at high pH. Appl. Geochem. 2000, 15, 327-335. [CrossRef]

27. Pabst, A. Synthesis, properties, and structure of $\mathrm{K}_{2} \mathrm{Ca}\left(\mathrm{CO}_{3}\right)_{2}$, Bütschliite. Am. Mineral. 1974, 59, 353-358.

28. Al-Wakeel, E.I.; El-Korashy, S.A. Reaction mechanism of the hydrothermally treated $\mathrm{CaO}-\mathrm{SiO}_{2}-\mathrm{Al}_{2} \mathrm{O}_{3}$ and $\mathrm{CaO}-\mathrm{SiO}_{2}-\mathrm{Al}_{2} \mathrm{O}_{3}-\mathrm{CaSO}_{4}$ systems. J. Mater. Sci. 1996, 31, 1909-1913. [CrossRef]

29. Klimesch, D.S.; Ray, A. DTA-TG study of the $\mathrm{CaO}-\mathrm{SiO}_{2}-\mathrm{H}_{2} \mathrm{O}$ and $\mathrm{CaO}-\mathrm{Al}_{2} \mathrm{O}_{3}-\mathrm{SiO}_{2}-\mathrm{H}_{2} \mathrm{O}$ systems under hydrothermal conditions. J. Therm. Anal. Calorim. 1999, 56, 27-34. [CrossRef]

30. Klimesch, D.S.; Ray, A. DTA-TGA evaluations of the $\mathrm{CaO}-\mathrm{Al}_{2} \mathrm{O}_{3}-\mathrm{SiO}_{2}-\mathrm{H}_{2} \mathrm{O}$ system treated hydrothermally. Thermochim. Acta 1999, 334, 115-122. [CrossRef]

31. Watanabe, O.; Kitamura, K.; Maenami, H.; Ishida, H. Hydrothermal treatment of a silica sand complex with lime. J. Am. Ceram. Soc. 2001, 84, 2318-2322. [CrossRef]

32. Kyritsis, K.; Meller, N.; Hall, C. Chemistry and morphology of hydrogarnets formed in cement-based CASH hydroceramics cured at 200 to $350{ }^{\circ}$ C. J. Am. Ceram. Soc. 2009, 92, 1105-1111. [CrossRef]

33. Guo, X.L.; Meng, F.J.; Shi, H.S. Microstructure and characterization of hydrothermal synthesis of Al-substituted tobermorite. Constr. Build. Mater. 2017, 133, 253-260. [CrossRef]

34. Organova, N.I.; Koporulina, E.V.; Ivanova, A.G.; Trubkini, N.V.; Zadov, A.E.; Khomyakov, A.P.; Marcille, I.M.; Chukanov, N.V.; Shmakov, A.N. Structure model of Al,K-substituted tobermorite and structural changes upon heating. Crystallogr. Rep. 2002, 47, 950-956. [CrossRef]

35. Hu, X.L.; Yanagisawa, K.; Onda, A.; Kajiyoshi, K. Stability and phase relations of dicalcium silicate hydrates under hydrothermal conditions. J. Ceram. Soc. Jpn. 2006, 114, 174-179. [CrossRef]

36. Pena, R.; Guerrero, A.; Goni, S. Hydrothermal treatment of bottom ash from the incineration of municipal solid waste: Retention of Cs(I), Cd(II), Pb(II) and Cr(III). J. Hazard. Mater. 2006, 129, 151-157. [CrossRef] [PubMed] 
37. Coleman, N.J. Interactions of Cd(II) with waste-derived 11 angstrom tobermorites. Sep. Purif. Technol. 2006, 48, 62-70. [CrossRef]

38. Hinsinger, P. Potassium. In Encyclopedia of Soil Science; Lal, R., Ed.; Marcel Dekker Inc.: New York, NY, USA, 2002; pp. 1354-1358.

39. Xu, R.K.; Zhao, A.Z.; Yuan, J.H.; Jiang, J. pH buffering capacity of acid soils from tropical and subtropical regions of China as influenced by incorporation of crop straw biochars. J. Soils Sediments 2012, 12, 494-502. [CrossRef]

40. Weaver, A.R.; Kissel, D.E.; Chen, F.; West, L.T.; Adkins, W.; Rickman, D.; Luvall, J.C. Mapping soil pH buffering capacity of selected fields in the coastal plain. Soil Sci. Soc. Am. J. 2004, 68, 662-668. [CrossRef]

41. Biagioni, C.; Merlino, S.; Bonaccorsi, E. The tobermorite supergroup: A new nomenclature. Mineral. Mag. 2015, 79, 485-495. [CrossRef]

42. Wang, Z.H.; Ma, S.H.; Zheng, S.L.; Wang, X.H. Incorporation of $\mathrm{Al}$ and $\mathrm{Na}$ in Hydrothermally Synthesized Tobermorite. J. Am. Ceram. Soc. 2017, 100, 792-799. [CrossRef]

43. Matsui, K.; Kikuma, J.; Tsunashima, M.; Ishikawa, T.; Matsuno, S.-Y.; Ogawa, A.; Sato, M. In situ time-resolved $\mathrm{X}$-ray diffraction of tobermorite formation in autoclaved aerated concrete: Influence of silica source reactivity and $\mathrm{Al}$ addition. Cem. Concr. Res. 2011, 41, 510-519. [CrossRef]

44. Maeda, H.; Abe, K.; Ishida, E.H. Hydrothermal synthesis of aluminum substituted tobermorite by using various crystal phases of alumina. J. Ceram. Soc. Jpn. 2011, 119, 375-377. [CrossRef]

45. Grew, E.S.; Locock, A.J.; Mills, S.J.; Galuskina, I.O.; Galuskin, E.V.; Halenius, U. Nomenclature of the garnet supergroup. Am. Mineral. 2013, 98, 785-810. [CrossRef]

46. Cohenaddad, C.; Ducros, P.; Bertaut, E.F. Etude de la substitution du groupement $\mathrm{SiO}_{4}$ par $(\mathrm{OH})_{4}$ dans les composes $\mathrm{Al}_{2} \mathrm{Ca}_{3}(\mathrm{OH})_{12}$ et $\mathrm{Al}_{2} \mathrm{Ca}_{3}\left(\mathrm{SiO}_{4}\right)_{2,16}(\mathrm{OH})_{3,36}$ de type grenat. Acta Crystallogr. 1967, 23, 220-230. [CrossRef]

47. Oneill, B.; Bass, J.D.; Rossman, G.R. Elastic properties of hydrogrossular garnet and implications for water in the upper-mantle. J. Geophys. Res. Solid Earth 1993, 98, 20031-20037. [CrossRef]

48. Okoronkwo, M.U.; Glasser, F.P. Compatibility of hydrogarnet, $\mathrm{Ca}_{3} \mathrm{Al}_{2}\left(\mathrm{SiO}_{4}\right)_{(\mathrm{x})}(\mathrm{OH})_{(4(3-\mathrm{x}))}$, with sulfate and carbonate-bearing cement phases: 5-85 ${ }^{\circ} \mathrm{C}$. Cem. Concr. Res. 2016, 83, 86-96. [CrossRef]

49. Adhikari, P.; Dharmawardhana, C.C.; Ching, W.Y. Structure and properties of hydrogrossular mineral series. J. Am. Ceram. Soc. 2017, 100, 4317-4330. [CrossRef]

50. Galvankova, L.; Masilko, J.; Solny, T.; Stepankova, E. Tobermorite synthesis under hydrothermal conditions. In Ecology and New Building Materials and Products 2016; Drdlova, M., Kubatova, D., Bohac, M., Eds.; Elsevier Science Bv: Amsterdam, The Netherlands, 2016; Volume 151, pp. 100-107.

51. Maeda, H.; Kurosaki, Y.; Nakamura, T.; Nakayama, M.; Ishida, E.H.; Kasuga, T. Control of chemical composition of hydrogrossular prepared by hydrothermal reaction. Mater. Lett. 2014, 131, 132-134. [CrossRef]

52. Grangeon, S.; Fernandez-Martinez, A.; Baronnet, A.; Marty, N.; Poulain, A.; Elkaim, E.; Roosz, C.; Gaboreau, S.; Henocq, P.; Claret, F. Quantitative X-ray pair distribution function analysis of nanocrystalline calcium silicate hydrates: A contribution to the understanding of cement chemistry. J. Appl. Crystallogr. 2017, 50, 14-21. [CrossRef] [PubMed]

53. Hou, D.S.; Ma, H.Y.; Li, Z.J. Morphology of calcium silicate hydrate (C-S-H) gel: A molecular dynamic study. Adv. Cem. Res. 2015, 27, 135-146. [CrossRef]

54. Grangeon, S.; Claret, F.; Lerouge, C.; Warmont, F.; Sato, T.; Anraku, S.; Numako, C.; Linard, Y.; Lanson, B. On the nature of structural disorder in calcium silicate hydrates with a calcium/silicon ratio similar to tobermorite. Cem. Concr. Res. 2013, 52, 31-37. [CrossRef]

55. Houston, J.R.; Maxwell, R.S.; Carroll, S.A. Transformation of meta-stable calcium silicate hydrates to tobermorite: Reaction kinetics and molecular structure from XRD and NMR spectroscopy. Geochem. Trans. 2009, 10, 14. [CrossRef] [PubMed]

56. Lothenbach, B.; Scrivener, K.; Hooton, R.D. Supplementary cementitious materials. Cem. Concr. Res. 2011, 41, 1244-1256. [CrossRef]

57. Shaw, S.; Clark, S.M.; Henderson, C.M.B. Hydrothermal formation of the calcium silicate hydrates, tobermorite $\left(\mathrm{Ca}_{5} \mathrm{Si}_{6} \mathrm{O}_{16}(\mathrm{OH})_{(2)} \cdot 4 \mathrm{H}_{(2)} \mathrm{O}\right)$ and xonotlite $\left(\mathrm{Ca}_{6} \mathrm{Si}_{6} \mathrm{O}_{17}(\mathrm{OH})_{(2)}\right)$ : An in situ synchrotron study. Chem. Geol. 2000, 167, 129-140. [CrossRef]

58. Mitsuda, T.; Sasaki, K.; Ishida, H. Phase evolution during autoclaving process of aerated concrete. J. Am. Ceram. Soc. 1992, 75, 1858-1863. [CrossRef] 
59. Zhang, P.; Ma, H.W. The synthesis of tobermorite from potassium feldspar powder: An experimental study. Acta Petrol. Et Mineral. 2005, 24, 333-338.

60. Qiu, M.Y.; Ma, H.W.; Nie, Y.M.; Zhang, P.; Liu, H. Experimental study on synthesis of tobermorite by decomposing potassium feldspar. Geoscience 2005, 19, 348-354.

61. Klimesch, D.S.; Ray, A. Effects of quartz particle size and kaolin on hydrogarnet formation during autoclaving. Cem. Concr. Res. 1998, 28, 1317-1323. [CrossRef]

62. Klimesch, D.S.; Ray, A. Hydrogarnet formation during autoclaving at $180{ }^{\circ} \mathrm{C}$ in unstirred metakaolin-lime-quartz slurries. Cem. Concr. Res. 1998, 28, 1109-1117. [CrossRef]

63. Klimesch, D.S.; Ray, A. Autoclaved cement-quartz pastes with metakaolin additions. Adv. Cem. Based Mater. 1998, 7, 109-118. [CrossRef]

64. Liu, Y.; Xia, H.; Ma, H. Kinetics of hydrothermal decomposition of potassium feldspar with calcium hydroxide. Adv. Mater. Res. 2012, 549, 65-69. [CrossRef]

65. Skorina, T.; Allanore, A. Aqueous alteration of potassium-bearing aluminosilicate minerals: From mechanism to processing. Green Chem. 2015, 17, 2123-2136. [CrossRef]

66. Eckert, J.O.; HungHouston, C.C.; Gersten, B.L.; Lencka, M.M.; Riman, R.E. Kinetics and mechanisms of hydrothermal synthesis of barium titanate. J. Am. Ceram. Soc. 1996, 79, 2929-2939. [CrossRef]

67. Berger, G.; Beaufort, D.; Lacharpagne, J.C. Experimental dissolution of sanidine under hydrothermal conditions: Mechanism and rate. Am. J. Sci. 2002, 302, 663-685. [CrossRef]

(C) 2019 by the authors. Licensee MDPI, Basel, Switzerland. This article is an open access article distributed under the terms and conditions of the Creative Commons Attribution (CC BY) license (http:/ / creativecommons.org/licenses/by/4.0/). 